(Halaman ini sengaja dikosongkan) 


\title{
PENGARUH ISLAM TERHADAP IDENTITAS TIDUNG MENURUT BUKTI ARKEOLOGI
}

\author{
Nugroho Nur Susanto
}

Balai Arkeologi Banjarmasin, Jalan Gotong Royong II, RT 03/06, Banjarbaru 70711, Kalimantan Selatan; Telepon (0511) 4781716; Facsimile (0511) 4781716; email: nugi_balarbjm@yahoo.com

Artikel masuk pada 8 Maret 2013

Artikel direvisi pada 20 Agustus 2013

Artikel selesai disunting pada 18 September 2013

\begin{abstract}
Abstrak. Suku Tidung banyak menempati wilayah timur Kalimantan bagian utara. Tidung adalah suku asli Kalimantan atau bagian dari Dayak, selain itu, nama Tidung juga menunjuk kepada sebuah kerajaan yang kental dengan nuansa Ke-Islaman. Penelitian ini bertujuan mengungkap siapa Tidung, mengapa Tidung memiliki identitas demikian dan bagaimana institusi yang dimilikinya. Dari analisis peninggalan arkeologi dan persebarannya pertanyaan ini dapat terjawab. Melalui analisis bukti makam, dan situs lainnya, memberi gambaran bahwa mereka adalah penduduk asli, karena bermukim di tempat yang strategis dan mendapat pengaruh yang intens dari budaya luar, maka identitas mereka berbeda dengan saudara-saudaranya.
\end{abstract}

Kata Kunci : Dayak, Tidung, Kerajaan Tidung, Islam Tidung

\begin{abstract}
THE INFLUENCES OF ISLAM ON THE TIDUNG PEOPLE IDENTITY BASED ON ARCHAEOLOGICAL EVIDENCE. Tidung people have occupied the most area in the north eastern Kalimantan. Tidung is indigenous people, being the part of Dayak Kalimantan. In addition, the name of Tidung also refers to a kingdom which is closed by Islamic nuance. This study aims to uncover who is Tidung, why Tidung have such identity and how its institutions. these questions can be answered by the analysis of the spreading of archaeological heritage. Through the analysis of evidence such as tombs, and findings from other sites, suggesting that Tidung is the indigenous people, as settled in a strategic place and has gotten of foreign cultures influence intensively, then their identity has become different from his brothers (Dayak).
\end{abstract}

Keywords: Dayak, Tidung Kingdom, Islamic Tidung.

\section{A. Pendahuluan}

\section{Latar Belakang dan Permasalahan}

Pada tahun 2007 muncul Undang-undang No. 34 yang mendasari pembentukan daerah tingkat II baru, yaitu Kabupaten Tana Tidung. Nama kabupaten baru, yang bernama Tana Tidung, didasarkan pada nama lama era kolonialisme : Afdeeling Tidoengschelanden (artinya Afdeling Tanah Tidung). Dalam benak kita kemudian muncul pertanyaan, siapa "tidung", latar belakang apa mengaitkan nama tersebut, sehingga menyangkut suatu nama komunitas, " tanah / wilayah politis" sebagai nama suatu daerah otonom. Pertanyaan 'siapa' dapat dikaitkan dengan genealogis keturunan, dan dikaitkan dengan ikatan emosional sejarah 'wilayah' dari masa lalu. Hal ini terkait pula dengan rasa, sikap emosional kolektifitas. Kadang muncul pertanyaan yang menggelitik "mengapa tidak mengambil nama sungai" seperti misalnya Kabupaten
Berau, atau Kabupaten Melawi. Akan sangat wajar apabila mengambil nama "Kabupaten Sesayap", untuk wilayah ini karena kesatuan geografis memungkinkan dapat menimbulkan emosi senasib yang mengikat. Atas kesamaan jalur, arus lalu lintas, yang telah menghidupi atas segala hajad hidup masyarakatnya. Atau nama kabupaten dikaitkan dengan nama kerajaan besar yang dahulu pernah berdaulat. Sebagai contoh, di Kalimantan Timur mengaitkan dengan Kerajaan Kutai yang kekuasaannya meliputi wilayah Kalimantan Timur. Dengan demikian, muncul nama Kabupaten Kutai Kertanegara, Kabupaten Kutai Timur, hingga Kutai Barat.

Tulisan ini dilatarbelakangi juga atas pertanyaan yang terkait dengan identitas suku "Tidung". Apakah mereka itu Melayu (Banjar) atau Dayak. Tentu ini berbeda dengan kemunculan nama Berau sebagai 
salah satu nama kabupaten besar di Kalimantan Timur, mengalahkan dikotomi nama sub-sub kerajaan masa lalu yaitu Kesultanan Gunung Tabur dan Kesultanan Sambaliung. Berau lebih layak, selain menggambarkan nama sungai besar, dan berpengaruh, juga memilki ide menyatukan dua kesultanan/kerajaan. Kesultanan Berau adalah kesultanan induk, masih dalam satu keluarga ketika Sambaliung dan Gunung Tabur masih bersatu.

\section{Tujuan dan Manfaat}

Masyarakat yang damai dan toleran perlu dibangun dengan pemahaman budaya dan mengerti sejarah. Keragaman Indonesia, khususnya Kalimantan adalah kenyataan sejarah yang harus disadari, sehingga bukan merupakan ancaman, tetapi merupakan kekayaan yang harus diakui keberadaannya. Tujuan penulisan artikel ini adalah memahami siapa Tidung, mengapa dan bagaimana "Tidung" dalam perjalanan sejarah budayanya. Memang harus diakui tidak banyak referensi tentang keberadaannya, apalagi dalam percaturan sejarah komunitas Asia Tenggara. Hasil penelitian ini diharapkan dapat merangkai sejarah keberadaan mereka, disadari oleh mereka, dan dipahami oleh orang lain, sehingga menimbulkan sikap saling menghormati dan menghargai di tengah keragaman identitas.

Manfaat penelitian ini diharapkan dapat menimbulkan sikap toleransi antarkelompok masyarakat, khususnya di Kalimantan. Dapat dijelaskan bahwa keragaman yang tidak disertai dengan sikap toleransi justru dapat menjadi sebuah ancaman, seperti halnya bahaya laten. Akan tetapi perbedaan di sisi lain, dapat dianggap sebagai potensi positif. Pemahaman yang mendasarkan pada pengetahuan yang benar diharapkan menimbulkan penyadaran akan keragaman, yang tidak mudah diadu domba. Situasi dan kondisi masa lalu yang berbeda, memunculkan kekayaan multi-kultural di Kalimantan.

\section{Kerangka Pikir}

Dikotomi oposisi binner, penghuni Pulau Kalimantan yang sering disematkan kepada masyarakatnya tidak selamanya benar dan menguntungkan. Oposisi binner ini biasanya menyangkut sistem religi, penghidupan atau cara pandang. Menempatkan dua kelompok, yang seolaholah berhadap-hadapan, posisi saling bertolakbelakang. Yaitu antara Dayak dihadapkan dengan Melayu (Banjar) di posisi lain, yang seakanakan sangat berbeda, bahkan berseberangan. Melayu (Banjar) beragama Islam, Dayak tidak/belum Islam. Melayu (Banjar) hidup di pantai / pesisir, sedangkan orang Dayak hidup di pedalaman. Banjar, terbuka terhadap pengaruh luar, Dayak tertutup, bahkan terkesan mengasingkan diri. Dayak jujur dan bersahaja, sedang Melayu (Banjar) mengakal dan suka hidup mewah, dll.

Bisa jadi hal ini benar, bagi cara pandang kaum kolonialis yang memanfaatkan situasi dan kondisi ini digunakan untuk memecah belah masyarakat Kalimantan pada saat itu. Pengetahuan sosial budaya tentang masyarakat digunakan dalam rangka untuk. IImuan sosial kolonialis diabdikan untuk misi kolonialisme, biasanya mereka mendefinisikan sesuatu, dan mengkategorisasikan terhadap suatu objek. Hal ini sah-sah saja, yang kemudian memberi "label" kepada "objek" yaitu masyarakat yang hendak dikuasainya. Knowledge is power, mengetahui untuk menguasai.

Pandangan di atas lambat laun memudar, seiring dengan alam kemerdekaan dan situasi keterbukaan, di mana informasi dapat menjangkau ke seluruh pelosok dan seluruh lapisan masyarakat. Dalam ilmu sosial, terlebih pada pengetahuan humaniora hampir tidak ada hukum, teori, atau pun aksioma yang bersifat menyeluruh, pasti, permanen, atau mutlak. Situasi dan kondisi begitu cair, dapat dengan mudah berubah, kebenaran kadang hanya bersifat temporal dan berlaku dalam lokalitas yang terbatas. Sifat pengetahuan ini dalam rangka memahami (inclaren), bukan pada posisi menjelaskan (vestehen), yang pada akhirnya terjebak pada penafsiran logika dan prasangka.

\section{Tinjauan Pustaka}

Masyarakat Dayak di bagian sisi utara Kalimantan, sejauh ini bisa jadi berbeda dalam hal keyakinan atau agama dengan peradaban di Muara Kaman kota yang muncul karena Mahakam. Agama Hindu menurut data arkeologis hanya sampai di Kuta Bangun melalui Sungai Mahakam saat Kerajaan Hindu Kutai Mulawarman berpengaruh. Bukti arca nandi (sapi) ditemukan di Kota Bangun dan Long Bagun. Ini mengingatkan pada daerah pinggiran, yang tentu berbeda dengan Muara Kaman sebagai pusat pemerintahan, pusat peradaban yang kaya peninggalan berupa Yupa, arca-arca yang kemudian diungsikan di Gunung Kombeng.

Suku Bahau, Apo Kayan atau mungkin Murut bisa jadi tidak berhadapan langsung dengan agama Hindu. Mereka bertemu Hindu lewat perantara atau jauh dari periode ketika agama Hindu dipeluk. Walaupun tidak dipungkiri pengaruh ini masih melekat dan dipertahankan. Misalnya oleh Suku Dayak Bahau mengenal nama dewa, Seng yang (Sang Hyang) atau kata Juwata, Jabata (dewata) yang juga di kenal bagi 
masyarakat Dayak di Kalimantan Selatan atau Kalimantan Tengah mengingatkan dengan ungkapan Tuhan bagi Agama Hindu. Nama-nama demikian memang digunakan, tetapi digambarkan jauh dari apa yang dimaksud dalam agama Hindu, terutama dalam menggambarkan ikonografi perwujudan atau arca. Pengaruh Hindu di Kalimantan Selatan lebih kuat dibanding daerah Kalimantan Timur (Scharer vide Coomans 1987, 16-17).

Ada satu pandangan, bahwa masuknya Islam di kalangan lingkup kerajaan atau bangsawan, seperti halnya pengaruh elit yang hanya kepala kaum terpelajar, atau saudagar besar. Ini menjadikan Islam muncul sebagai suatu ikatan, religius, politik dan kekuatan sosio-ekonomi. Mereka tidak mencari hubungan sosial kepada / dengan orang Dayak yang dianggap kafir. Di sisi lain, Orang Dayak yang merasa diri dipandang rendah, sehingga mereka pun tidak mencari hubungan sosial dengan mereka. Nampak sekali ada ketegangan antarkelompok sosial tersebut di pedalaman. Hal ini diperkuat pula ada diskriminasi antara Islam dengan Dayak dihadapan hukum dan pajak (Van Rongkel vide Comans 1987, 32).

Dalam melihat budaya suatu masyarakat, diyakini bahwa ciri atau identitas itu dibentuk atau dibangun, tetapi kalangan intelektual saling berbeda pendapat mengenai seberapa jauh konstruksi identitas budaya berkaitan dengan proses-proses budaya dan pengalaman-pengalaman sejarah yang berbeda-beda (Maunati 2004, 23). Misalnya kata Dayak oleh sebagian ahli dan pemerhati Kalimantan diidentikkan dengan stam-stam yang belum/tidak beragama Islam, mereka mendiami bagian pedalaman, hulu sungai atau sering disebut orang gunung. Istilah Dayak biasanya dibenturkan dengan kata Melayu, yang seakan diartikan sebagai "suatu yang berseberangan". Melayu beragama Islam, mendiami daerah pantai atau pinggir sungai atau kepulauan. Salah satu komunitas 'pribumi" yang akan disoroti di dalam artikel ini adalah Suku Tidung, suatu komunitas "pribumi" yang banyak mendiami Kalimantan Timur bagian utara.

Tjilik Riwut memandang Suku Tidung bukan merupakan sub suku yang besar, mereka merupakan bagian dari keluarga Dayak Murut. Penyebaran dan lokasi terbatas yaitu di tengah Pulau Kalimantan agak di pedalaman. Tjilik Riwut membagi Dayak dalam 6 kelompok Besar: (1) Ngaju (2) Apu Kayan, (3) Iban (4) Klemantan, (5) Murut, dan (6) Punan. Suku Tidung merupakan bagian dari kelompuk Dayak Murut. Yang menurut Tjilik Riwut suku Tidung ini dibagi atas 10 kelompok subsuku yang lebih kecil. Dayak Murut mendiami bagian di utara Kalimantan bagian timur. (Riwut 2003, 62). Salah satu risalah yang ditulis oleh almarhum Datu Mohammad Saleh atau Datu Perdana, anak Datu Mansyur pengemban kekuasaan Kesultanan Bulungan periode 1938-1949 menyebutkan, bahwa pada tahun 1948 penduduk Kesultanan Bulungan berjumlah 90.000 jiwa. Dari penduduk tersebut terbagi menjadi 3 bagian menurut catatan statistik KUA, $55 \%$ Heiden (belum mengenal agama) atau menganut agama asli. Sekitar $5 \%$ menganut agama Kingmi (Kristen), dan $20 \%$ masyarakat Bulungan dan Tidung yang telah beragama Islam, sisanya tidak ada catatan (Ferdana 1949, 10).

Mika Okusima pada tahun 2002 meneliti tentang keberadaan Suku Dayak Tidung melalui persebaran rumpun bahasanya. Studi ini diperoleh kesimpulan bahwa persebaran Tidung sangat luas, mulai daerah pesisir Berau, Sangata, Malinau, Sesayap, Tarakan, Bunyu, Sandakan, hingga Sabah. Dari segi bahasa, bahkan ada unsur kata yang sama / mirip dengan bahasa yang ada di Sulu (Filipina Selatan).

Pada hari Kamis 16/8/2007 di sebuah web (http:thetidung.blogspot.com/2007/)ada sebuah artikel, yang memuat Raja-raja Kerajaan Tarakan, sebuah hegemoni politik Tidung, yang mereka sebut sebagai Dinasti Tenggara. Dinasti "Tidung" diklaim mulai ada sejak tahun 1557 yang berlangsung hingga tahun 1916. Raja atau penguasa lokal secara berturut-turut, adalah:

a. Amiril Rasyid gelar Gelar Datu Raja Laut, 1557-1571;

b. Amiril Pangiran Dipati I (1571 - 1613);

c. Amiril Pangiran Singa Laut (1613-1650);

d. Amiril Pangiran Maharaja Jalila I ( 650-1695);

e. Amiril Pangiran Maharaja Jalila II (1695- 1731);

f. Amiril Pangiran Dipati II (1731- 1765);

g. Amiril Pangiran Maharaja I (1765- 1782);

h. Amiril Pangiran Maharaja Jalila III (1782- 1817);

i. Amiril Tadjuddin (1817-1844);

j. Amiril Pangiran djamalul Kirm (1844-1867);

k. Ratu Intan Dura/Datu Maulana (1867-1896); dan

I. Datu Adil (1896-1916).

Penguasa hegemoni ini hingga 12 suksesi yang diakhiri tokoh legendaris Tidung sekaligus anti Belanda, yaitu Datu Adil yang memerintah tahun 1896 hingga tahun 1916. Penguasa Tidung sekaligus Sultan Bulungan, yang memiliki darah keturunan Tidung ini menjadi kontroversi. Selain tidak mendapat simpati dari sebagian bangsawan, ia juga anti Belanda yang pada saat itu memiliki hegemoni yang sangat kuat mencengkeram Bulungan.

Artikel ini tidak bermaksud mempertentangkan keberadaan Kesultanan Bulungan dan keberadaan Tidung yang menimbulkan gelombang pro-kontra, mengarah pada emosional etnisitas dan lokalitas. Banyak sanggahan atas klaim "Kerajaan Tidung," walaupun ada pula yang mempertahankan pendapat 
ini dengan mengemukakan berbagai macam dalih. Sanggahan atas pendapat inipun sangat kuat, apalagi terkait dengan bukti sejarah yang minim. Tulisan ini membatasi permasalahan "Tidung" terkait dengan bukti arkeologi yang dikaitkan dengan interpretasi kewilayahannya.

\section{Metode Penelitian}

Kedudukan ilmu sejarah dan arkeologi sangat erat, antara keduanya dapat saling mengisi. Dalam permasalahan klaim kebenaran antara pendekatan sejarah dan ilmu arkeologi dapat saling mendukung. Keberadaan bukti sejarah berupa benda material dimanfaatkan untuk hadir sebagai bukti pendukung. Sebaliknya, dari bukti arkeologi dapat menggambarkan situasi dan kondisi masa lalu terkait dengan persebaran dan pusat budayanya.

Arkeologi didefinisikan sebagai ilmu yang bertujuan merekonstruksi kehidupan manusia masa lalu atau sejarah melalui peninggalan materialnya. Ada dua macam bukti material menurut kedudukannya yaitu yang ada di atas permukaan tanah, yang dapat diketahui dengan metode survei permukaan, dan data yang ada di bawah permukaan tanah. Untuk memperoleh data yang disebut terakhir dapat diperoleh melalui metode ekskavasi.

Metode pengumpulan data pada penelitian ini bersifat eksploratif artinya berusaha mengumpulkan data yang ada di lapangan, kemudian diklasifikasi dan dianalisis dari faktor kedekatan lokasi dan periodisasi situs. Bukti material di sini tentu tidak mungkin terjaring seluruhnya dalam cakupan kehidupan manusia yang tak terbatas, tetapi dibatasi oleh ruang dan waktu wilayah penelitian. Pada data permukaan pun yang diperoleh melalui survei juga terbentur pada keterbatasan, antara lain material yang mudah rusak, sering hilang dan keberadaannya penuh "nuansa" kepentingan. Di dalam studi arkeologi kekuatan bukti di permukaan tanah dalam hal ini pengamatan belum bersifat khas, karena ada metode yang lebih spesifik yaitu ekskavasi yang saat ini belum dilakukan.

\section{B. Pembahasan}

\section{Profil Daerah Penelitian}

Kabupaten Tana Tidung merupakan kabupaten hasil pemekaran dari Kabupaten Bulungan berdasarkan UU RI No. 34 tahun 2007. Awalnya kabupaten ini masuk dalam wilayah Propinsi Kalimantan Timur, tapi sejak 17 November 2012 berdasarkan Undang-Undang Nomor 20 Tahun 2012 Tentang Pembentukan Propinsi Kalimantan Utara wilayah Kabupaten Tana Tidung termasuk dalam
Propinsi Kalimantan Utara (merupakan pemekaran dari propinsi Kalimantan Timur). Luas Kabupaten Tana Tidung 4.815,58 km2, terdiri atas 3 kecamatan yaitu Kecamatan Sesayap, Sesayap Hilir, dan Tana Lia. Pada saat ini sudah dimekarkan 2 kecamatan baru, yaitu Muruk Rian dan Kecamatan Betayau (BPS Kabupaten Tana Tidung Dalam Angka 2010).

Kecamatan Tanah Lia terdiri atas 3 desa, yaitu Desa Sambungan, Tanah Merah danTengku Dacing. Kecamatan Sesayap Hilir 8 Desa: Desa Badan Bikis, Bebatu, Buong Baru, Menjelutung, Seludan, Sengkong, Sepala Dalung, Sesayap Dalung, Sesayap Sepala. Kecamatan Sesayap terdiri atas Desa Bebakung, Gunawan, Kujau, Limbu Sedulum, Mandupe, Sebawang, Sebidai, Sedulum, Seputuk, Tideng Pale, dan Tidung Pale Timur.

Secara geografis Kabupaten Tana Tidung

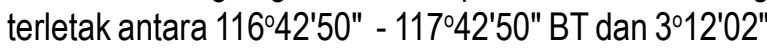
- 3046'41" LU. Kabupaten Tana Tidung bagian utara berbatasan dengan Kabupaten Nunukan, bagian timur dengan Laut Sulawesi, Kabupaten Bulungan (P. Bunyu) dan Kota Tarakan, bagian selatan dengan Kabupaten Bulungan, dan bagian barat dengan Kabupaten Malinau. (BPS Kabupaten Tana Tidung Dalam Angka 2010).

\section{Sejarah Kabupaten Tanah Tidung}

Kabupaten Tana Tidung adalah salah satu Kabupaten di Propinsi Kalimantan Timur, Indonesia yang baru disetujui pembentukannya pada Sidang Paripurna DPR RI pada tanggal 17 Juli 2007, bersama pembentukan kabupaten/kota baru sebanyak 14 di seluruh Indonesia. Kabupaten ini merupakan pemekaran dari tiga wilayah kecamatan di Kabupaten Bulungan, yakni Kecamatan Sesayap, Sesayap Hilir dan Tanah Lia. (BPS Kabupaten Tana Tidung Dalam Angka 2010).

Asal-usul nama Tideng Pale, ibukota Kabupaten Tana Tidung ini memang unik dengan ejaannya yang khas Tideng Pale (baca: Tidung Pala), Nama Tideng Pale berasal dari dua kosakata yakni "Tideng" dan "Pale". Dalam Bahasa Tidung "Tideng" artinya gunung sementara "pale" berarti "tawar atau hambar", jika disatukan maka bermakna "Gunung Hambar". Gunung Hambar yang dimaksud adalah daerah yang berada di bawah kaki gunung yang mengalir Sungai Sesayap. Air Sungai Sesayap ini jika terjadi musim kemarau maka daerah tersebut adalah perbatasan antara air sungai yang berasa tawar dan air sungai yang berasa asin, maka disebutlah Tideng Pale atau gunung pembatas antara air tawar dan air asin. (BPS Kabupaten Tana Tidung Dalam Angka 2010). 
Pada penelitian ini ditampilkan pula data arkeologi yang berada di luar wilayah administrasi Kabupaten Tanah Tidung, misalnya di Kabupaten Bulungan dan Kota Tarakan. Bukti arkeologi tersebut tidak bisa ditinggalkan, karena secara wilayah budaya ada hubungan dan secara kronologis sejarahnya saling mempengaruhi.

\section{Situs-situs Bukti Arkeologi di Wilayah Penelitian}

a. Makam Sultan Amiril Mukminin

Makam tunggal, tetapi dapat dianggap sebagai makam terpenting dari periode Kesultanan Bulungan, sekaligus tokoh yang menurunkan "penguasa" Tidung ini adalah yang merupakan makam seorang sultan yang menurut masyarakat disebut makam Amiril Mukminin. Makam ini terletak di atas bukit Baratan, merupakan makam satu-satunya'. Secara administrasi terletak di Desa Baratan, Kecamatan Tanjung Selor,Kabupaten Bulungan. Pada sebelah kanan apabila dari arah hulu atau sisi selatan dari aliran Sungai Kayan. Gunung Baratan sendiri terletak pada bagian meander Sungai Kayan/ Bulungan. Di lokasi ini, terdapat sebuah makam saja, yaitu makam Wira Amir yang merupakan salah satu sultan, yang terkemuka berperan dalam merintis penyebaran agama Islam di wilayah Bulungan². Makam Wira Amir ini memiliki nisan yang dibuat dari batu andesit yang berbentuk gada dengan pola hias sulur-suluran yang cukup raya (Atmojo 2000, 23).

Motif hias didominasi oleh bentuk sulur-suluran, daun, dan bunga yang terdapat hampir di seluruh sisi nisan yang memiliki ukuran panjang 40 centimeter dan lebar 26 centimeter, dengan diameter \pm 78 centimeter. Dulunya, makam ini memiliki batas batu yang dibuat dari jenis batu yang sama dengan nisannya. Batas tersebut berupa bongkahan batu berbentuk persegi panjang dengan motif hias sulur-suluran di seluruh sisinya. Batu-batu tersebut disusun sehingga membentuk batas makam berbentuk persegi panjang. Saat ini, batas tersebut digantikan dengan semen yang dilapisi keramik. Sebuah bangunan cungkup juga didirikan untuk melindungi makam ini dari hujan dan terik matahari. Tetapi, sebelum naik ke bukit di bagian agak ke hulu sungai Kayan dari lokasi makam Sultan Amiril, kurang lebih $550 \mathrm{~m}$ terdapat kampung Baratan. Di kampung ini dahulu pusat pemerintahan masa awal Kesultanan Bulungan pernah berlangsung dan ada sebuah tempat ibadah, umat Islam awal pernah didirikan di lokasi ini. Dauh atau beduk yang terdapat di masjid Jami Kasimuddin konon berasal dari kampung Baratan.

\section{b. Makam Said Ahmad Maghribi, penyiar agama Islam di Salim Batu}

Kompleks makam Said Ahmad Maghribi ini berada di Desa Salim Batu Kecamatan Tanjung Palas, Kabupaten Bulungan. Makam ini terletak di lereng tebing yang berada di sebelah barat aliran Sungai Pimping yang bermuara di Teluk Sekatak. Pada kompleks makam ini terdapat 1 buah cungkup yang di dalamnya ada 3 buah makam. Salah satunya adalah makam Said Ahmad Maghribi yang memiliki nisan kepala dari batu berbentuk gada dengan ukuran panjang 33 centimeter dan lebar 20 centimeter. Sementara itu, nisan kakinya juga terbuat dari batu yang berbentuk bulat lonjong dengan panjang 30 centimeter dan lebar 20 centimeter. Nisan ini memiliki catatan tahun wafatnya yang berangka tahun 1832 .

Makam selanjutnya adalah makan Datu Iskandar yang memiliki nisan kayu yang berbentuk gada ramping setinggi 67 centimeter. Penampang lintang gada tersebut adalah bentuk segi delapan dengan lebar masing-masing sisinya yaitu 8 centimeter. Makam yang terakhir tidak diketahui identitasnya. Makam tersebut memiliki nisan dari batu yang berbentuk gada gemuk dengan panjang 28 centimeter dan lebar 15 centimeter. Selain makam yang ada di dalam cungkup, terdapat

Cerita rakyat Simung Luang yang bersuami Sadang berhasil membangun perkampungan di Baratan, kemudian pucuk pimpinan adat digantikan oleh Asung Luang. Pada saat itu komunitas Kayan sedang bermusuhan dengan Dayak Kenyah yang dipimpin oleh Sumbang Lawing, Asung Luang mau diperistri asalkan Datu Mancang membalas sakit hatinya karena saudaranya yang dibunuhnya, kepemimpinan kemudian dipegang oleh Datu Mancang dan Sinawai Luang inilah datang seorang bangsawan Brunai yang bernama Datu Mancang, singkat cerita Datu Mancang berhasil memperistri Asung Luang dan dari perkawinan ini lahirlah Kenawai Luang. Menurut Dali saat Datu Mancang memegang pimpinan terjadi sekitar tahun 1555 dan berakhir hingga tahun 1595, periode ini disebut sebagai Wira. Dan kemudian pemerintahan berikutnya digantikan oleh menantu Datuk Mancang bernama Singa Laut (1595-1618), seorang penjelajah dari Sulu setelah menikah dengan Kenawai Luang. Dan berturut-turut pemerintahan dipegang oleh Wira Kelana, anak dari Singa Laut. Wira Kelana diperkirakan memerintah 1618-1640 dan digantikan oleh anaknya bernama Wira Keranda ( diperkirakan memerintah dari 1640-1695), kemudian digantikan oleh Wira Digendung yang diperkirakan memerintah 1695 hingga 1731). Mulai tahun 1731 pemerintahan dipegang oleh Wira Amir yang bergelar Sultan Amiril Mukminin yang memerintah hingga tahun 1777.

2 Cerita di atas genealogi raja-raja Bulungan terkait nama Kayan, mulai dari Kuanyi, Lemlai Suri, Jau Iru, Paren Anyi, Wan Paren Lahai Bara, Sibarau, Simun Luang anaknya Kenawai Lumu. Saat mulai era Datu Mancang dan Singa laut (Abdurrasyid) nama Kayan tidak muncul lagi kecuali Cinaran Bulan. Setelah periode Singa Laut disebut periode Wira, yaitu mulai dari anak dari Singa Laut yaitu Wira Kelana, Wira Keranda, Wira Digendung, dan Wira Amir (Sultan Amiril Mukminin). 
juga makam lainnya yang tersebar di sekitar cungkup pada lereng-lereng bukit.

\section{c. Kompleks Makam Ali Idrus dan Said Abdullah Bil Faqih di Salimbatu}

Kompleks makam ini terletak di Desa Salim Batu, Kecamatan Tanjung Palas. Kabupaten Bulungan. Saat ini lokasi makam berada di tengah pemukiman warga dan dikelilingi oleh pohon berkayu dan semak-semak. Makam juga menjadi kompleks pemakaman umum bagi warga di sekitarnya. Secara umum, makammakam kuno di kompleks ini memiliki nisan yang terbuat dari kayu dengan bentuk pipih dan gada, nisan batu dengan bentuk gada, dan nisan batu yang berbentuk bulat lonjong seperti lingga. Di kompleks ini terdapat dua buah cungkup yang menaungi makam Ali Idrus dan Said Abdullah Bil Faqih (Atmojo 2002; Susanto 2012)

Di luar cungkup, di antara nisan-nisan yang tersusun tidak beraturan di kompleks makam, terdapat sebuah nisan batu yang cukup menarik. Nisan tersebut berbentuk seperti gada dengan penampang segi delapan yang melebar pada setiap tingkat ke bawahnya. Bagian paling atas berupa bangun persegi delapan. Bagian tengah ke bagian bawah memiliki bentuk yang menyempit dengan motif hias berupa sulursuluran dan garis geometri. Secara umum, nisan ini memiliki panjang 70 centimeter dan lebar 37 centimeter. Tidak terdapat inskripsi atau keterangan yang dapat digunakan untuk mengidentifikasi makam ini. Dan di antara makam-makam lainnya di kompleks ini tidak terdapat bentuk yang sama dengan nisan ini.

\section{d. Kompleks Makam Ratu Intan}

Kompleks makam ini berada di Desa Salim Batu, Kecamatan Tanjung Palas, Kabupaten Bulungan. Terletak di sebelah selatan Sungai Kayan atau

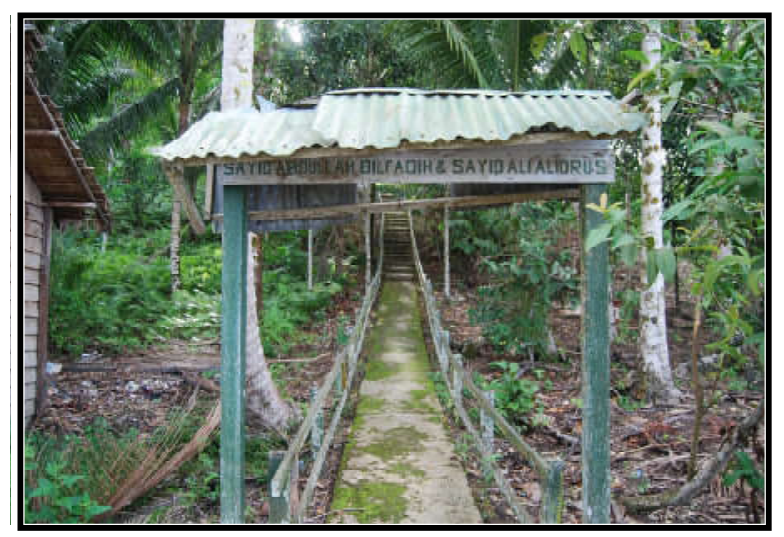

Foto 1. Komplek Makam penyiar agama Islam, Sayid Abdurrahman Bilfaqih (dok. Balai Arkeologi Banjarmasin).
Bulungan dan persimpangan Sungai Pimping. Di dalam kompleks makam ini terdapat makam-makam keturunan kerabat Kesultanan Bulungan, yang berasal dari Tidung di antaranya adalah Ratu Intan (1896), Datu Adil (1916), Datu Kahar (1940), Datu Ahmad (1941), dan Datu Kaharuddin (1989).

Makam Ratu Intan memiliki nisan yang dibuat dari batu andesit, terdiri atas tiga buah nisan, yaitu nisan kepala, nisan bagian tengah, dan nisan kaki. Nisan kepala berbentuk pipih dengan ukuran panjang 110 centimeter dan lebar 67 centimeter serta tebal 10 centimeter. Nisan kepala ini memiliki hiasan yang cukup raya berupa motif flora atau sulur-suluran, daun serta bunga. Nisan bagian tengah memiliki bentuk seperti daun dengan ujung yang meruncing. Nisan ini memiliki panjang 53 centimeter dengan lebar 42 centimeter. Sementara itu nisan kaki memiliki bentuk yang sama dengan nisan pada bagian tengah, dengan ukuran panjang 24 centimeter dan lebar 34 centimeter. Pada bagian sisi dari makam terdapat balok batu berbentuk persegi panjang dengan ukuran panjang 30 centimeter dan lebar 30 centimeter. Balok tersebut disusun sehingga mengelilingi makam. Nisan kaki menjadi penutupnya, sehingga makam tertutup oleh balok batu. Sementara itu bentuk makam yang lain adalah sebagai berikut. Datu Adil, Datu Kahar, Datu Ahmad, dan Datu Kaharuddin (Susanto 2012).

\section{e. Kompleks Makam Sultan Apit Gunung}

Kompleks makam ini berada di puncak bukit di Desa Salim Batu, Kecamatan Tanjung Palas, Kabupaten Bulungan. Bukit ini berada di sebelah utara aliran Sungai Pimping. Di lokasi ini terdapat 2 buah makam dari dua orang sultan yang meninggal akibat

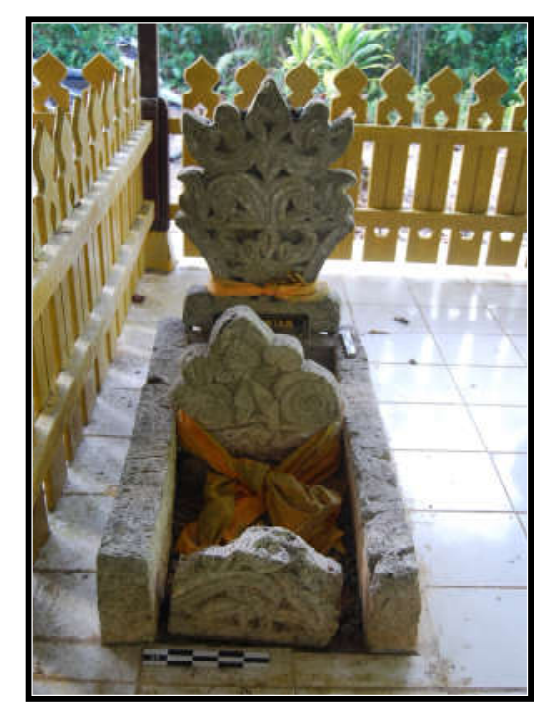

Foto 2. Makam Ratu Intan (dok. Balai Arkeologi Banjarmasin). 
berkelahi satu sama lain karena memperebutkan seorang perempuan. Berdasarkan keterangan dari warga, cerita mengenai latar belakang perkelahian yang disebabkan oleh perebutan perempuan, menyebabkan masyarakat tidak terlalu bersimpati kepada kedua sultan tersebut.

Kedua makam tersebut memiliki nisan dari kayu ulin berbentuk gada dengan balok kayu yang mengelilingi masing-masing makam. Makam 1 memiliki nisan dengan panjang $103 \mathrm{~cm}$, tingkat pertama balok kayu berukuran panjang $127 \mathrm{~cm}$ dan lebar $57 \mathrm{~cm}$, sedangkan tingkat kedua balok kayu berukuran panjang $147 \mathrm{~cm}$ dan lebar $84 \mathrm{~cm}$. Adapun makam 2 memiliki nisan dengan panjang 105 centimeter, dengan tingkat pertama balok kayu berukuran panjang $100 \mathrm{~cm}$ dan lebar $60 \mathrm{~cm}$, dan tingkat kedua balok kayu berukuran panjang $130 \mathrm{~cm}$ dan lebar $87 \mathrm{~cm}$. Dulunya terdapat inskripsi pada kedua makam, tetapi sekarang inskripsi tersebut sudah aus dan hilang.

\section{f. Makam Syekh Muhammad Al Marjak dan Makam Syekh Muhammad Al Idrus di Pamusian, Pulau Tarakan}

Makam tokoh ulama Syeh Muhammad Al Marjak dan Makam Syeh Muhammad Al Idrus terletak di tepi Sungai Pamusian, Kelurahan Kampung Enam, Kecamatan Tarakan Timur. Makam ini banyak dikunjungi oleh peziarah dan sangat dihormati oleh masyarakat Tarakan, khususnya masyarakat muslim Tidung. Tokoh pertama Syekh Muhammad Al Marjak dipercayai oleh masyarakat konon, berasal langsung dari Arab, sedangkan tokoh kedua dipercayai berasal dari Salim Batu, tokoh yang datang belakangan. Kedua tokoh ulama inilah mengenalkan Islam bagi masyarakat Tarakan, khususnya masyarakat Tidung. Sayang sekali tidak ada inskripsi tahun pada makam tersebut. Hanya menunjukkan Fam/marga mereka sama dengan tokoh penyebar Islam di Salim Batu yang hidup pada abad -18 Masehi (Susanto 2009, 40-51).

\section{g. Situs Batu Mapan di Desa Tidung Pala Kecamatan Sesayap}

Letak administrasi Situs Batu Mapan terletak di Desa Tideng Pala Kecamatan Sesayap, Kabupaten Tana Tidung, kurang lebih $4 \mathrm{Km}$ sebelah timur dari pusat kota Tidung Pala. Saat ini wilayah ini dipersiapkan sebagai kawasan perkantoran. Situs ini merupakan tempat yang dikeramatkan bagi masyarakat Tidung. Nilai penting tersebut terungkap dari beberapa keterangan yang menyebutkan bahwa Batu Mapan ini merupakan tempat bersemedi bagi Maharaja Dinda IV seorang tokoh penting masyarakat Tidung di wilayah Tanah Tidung (Armansyah Ali). Situs
Batu Mapan berada pada sebuah bukit dengan ketinggian $40 \mathrm{~m}$ dari permukaan air laut (Susanto 2013).

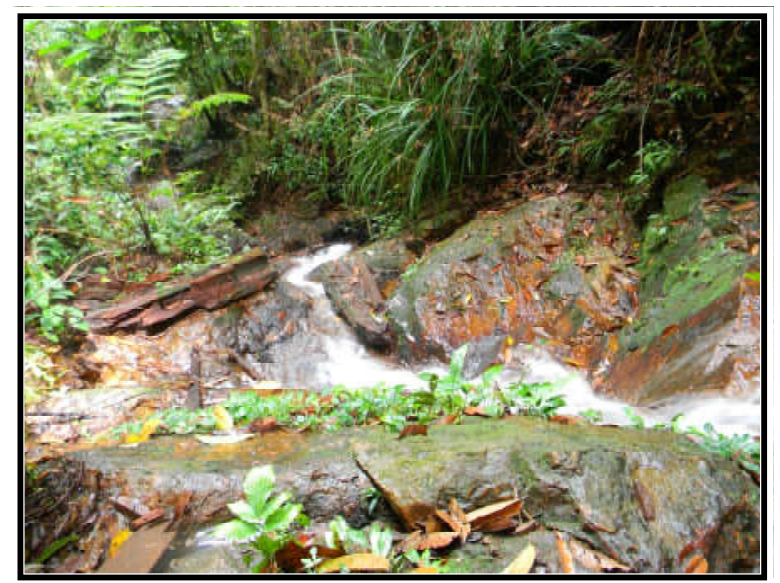

Foto 3. Situs Batu Mapan (dok. Balai Arkeologi Banjarmasin).

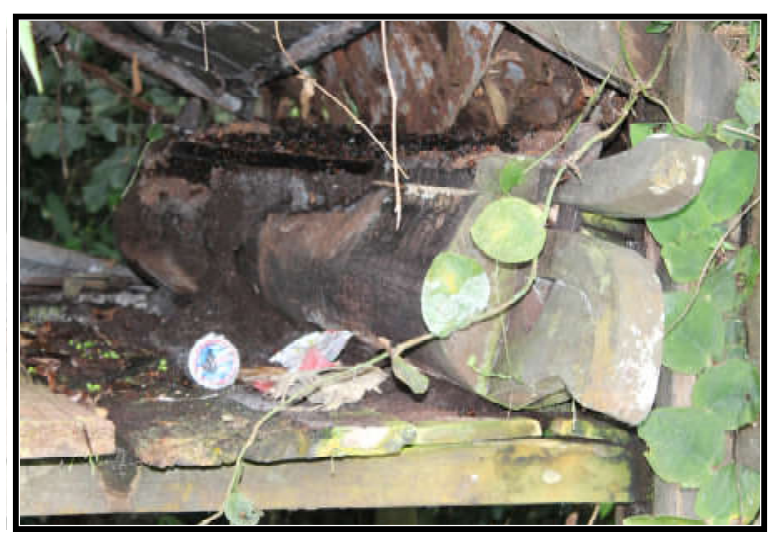

Foto 4. Tradisi penguburan lungun (dok. Balai Arkeologi Banjarmasin).

\section{h. Situs Tradisi Penguburan Dayak: Lungun Ilui di Sesayap Hulu}

Tradisi penguburan menggunakan lungun masih dapat dijumpai di Desa Seludau, Kecamatan Sesayap Hilir, Kabupaten Tana Tidung. Tradisi ini sebenarnya juga dimiliki oleh Tidung saat belum memasuki agama Islam. Secara adat, penempatan area makam terletak di luar pemukiman atau sekitar 700 meter dari perkampungan. Saat ini tradisi penguburan menggunakan lungun pada umumnya sudah ditinggalkan, apalagi penggunaan lungun secara permanen/langsung. Umumnya peti mati /lungun saat ini langsung dikubur (Yanat, 50).

Ada satu lungun yang juga masih ada hubungan keluarga dengan Yanat dan keluarga llayu, yaitu Lungun Ilui (milik tokoh bernama llui). Masyarakat di Seludau ini merupakan komunitas Belusu yang dituakan. Lungun berada dalam suatu bangunan kayu yang dihiasi dengan patung antropomorfik pada tiang dan seperti bangunan rumah-rumahan yang dibuat dari 
kayu. Lungun Ilui memiliki panjang 2, $68 \mathrm{~m}$ lebar 33 $\mathrm{cm}$ dan tinggi sekitar $30 \mathrm{Cm}$. Di area makam kuna saat ini dijadikan makam umum, bangunan makam dibuat rendah dan tradisi penguburan dengan lungun yang berlaku sekarang adalah dikubur di dalam tanah.

\section{i. Makam Sayid Alwi bin Alkaf, di Sesayap Hilir} Makam Habib Sayid Alwi bin Syeh bin Alwi Alkaf secara administrasi terletak di Desa Sesayap, Kecamatan sesayap Hilir, Kabupaten Tanah Tidung. Menurut salah seorang kerabat bernama Sayid Ali, 65 tahun. Tokoh yang dimakamkan ini bernama Sayid Alfi bin Sayid Alkaf. la merupakan tokoh penentang Belanda yang berasal dari Palembang. Makam secara umum sangat sederhana dan menggunakan batu alam sebagai nisan dan jirat makam yang terbuat dari porselin. Pada sisi atas makam tertulis Habib Alwi Alkaf. Informasi tokoh lebih lanjut di dapat dari manakib Al Habib Alwy bin Syeh Alkaf. Tokoh Habib Alwi bin Habib Alkaf dilahirkan di Palembang pada tahun $1837 \mathrm{M}$. Dia merupakan anak pertama dari tujuh bersaudara. Ibu Habib Alwi adalah keturunan Sultan Palembang, dan ayahnya seorang Habib syeh Al Kaf. Atas laporan L.W.C. Van de Berg seorang petinggi Belanda di Palembang, melaporkan bahwa Sayid Alwi sangat anti Belanda dan harus disingkirkan dari Palembang. Saran ini menghartarkan Sayid Habib Alwi di asingkan ke Pulau Tarakan. Kemudian dipindahkan ke Bulungan, dan oleh Sultan Bulungan diangkat sebagai "penasehat agama" diberi gelar 'Guru tua'. Selain menjadi ahli agama Beliau ahli dalam pengobatan (Susanto 2013).

Al Habib memiliki beberapa istri. Istri pertama bernama Nci Asim bermarga Al Jufri dari Sebakung, istri kedua Halijah, putra Pengeran Lagenda Betayau, istri ketiga bernama Pungun dari Tidung di Sesayap, dan istri keempat bernama Kitong saudara Pengeran Malinau. Dari perkawinan istri kedua hingga keempat beliau menurunkan ulama-ulama yang berdakwah di sekitar Sesayap, Bulungan, Tarakan, Berau, Sekatak, bahkan Tawau.

\section{j. Situs Makam Maharaja Dinda I di Sesayap Hilir}

Lokasi makam terpencil dari perkampungan, terletak di kebun atau ladang yang dipelihara Bapak Mahkota, 70 tahun. Secara administrasi makam terletak di Desa Sesayap, Kecamatan Sesayap Hilir, Kabupaten Tana Tidung. Pada awalnya makam ini hanya terdiri atas nisan tunggal, dari batu alam/monolit dengan tinggi $44 \mathrm{Cm}$. Makam sudah dibuat permanen dengan keramik pada jirat makam dan ruang tokoh utama dengan kelilingi dengan disemen cor sederhana.

Tidak jauh dari makam terdapat Sungai Selor, sungai inilah menjadi penghubung dengan Sungai
Sesayap atau dengan daerah lain. Tidak jauh dari makam masih dapat ditemukan tradisi 'menyanggar', yaitu bangunan rumah-rumahan yang berisi saji-sajian.

k. Koleksi Meriam Suku Tidung di Sesayap Hilir Sebuah meriam terbuat dari bahan kuningan saat ini disimpan oleh juru kunci makam Maharaja Dinda I yang bernama Pak Mahkota. Meriam ini ditemukan tidak jauh dari Desa Sesayap, sebuah desa tua yang berada di tepi Sungai Sesayap. Panjang meriam seluruhnya $145 \mathrm{~cm}$. Keliling bagian depan $25 \mathrm{~cm}$, atau diameter $17 \mathrm{~cm}$ dan diameter terbesar $37 \mathrm{~cm}$. Pada bagian pangkal bawah meriam ada tonjolan besi yang fleksibel. Objek ini menandakan bahwa meriam biasanya ditempatkan pada obyek tetap yang bergerak, misalnya kapal.

Oleh pak Mahkota, meriam ini disimpan dan dianggap masih keramat. Diselimuti kain kuning. Penuturan tetua meriam ini termasuk benda regalia penguasa "Tidung' walau secara politis "Kerajaan' Tidung sangat lemah tetapi memiliki penduduk yang tersebar.

\section{Makam di Kecamatan Tanah Lia, Pulau Mandul}

Situs makam nenek moyang awal Suku Tidung ini terletak di perkebunan di luar kampung yang banyak ditumbuhi pohon bambu. Untuk menjangkau daerah ini, kita dapat menyusuri Sungai Mandul, sehingga makam ini sering disebut Keramat Mandul. Ada dua lokasi makam yang berjarak kurang lebih 50 meter. Secara administrasi Desa Mandul terletak di Kecamatan Tanah Lia, Kabupaten Tana Tidung.

\section{(1). Makam Datu Bendahara}

Lokasi kompleks makam keramat secara administrasi berada di Desa Mandul, Kecamatan Tanah Lia. Kabupaten Tanah Tidung. Saat ini berada dalam suatu ruangan tertutup yang terdiri atas satu makam utama dan lima makam ukuran lebih kecil. Makam utama, menurut informan Datu Bendahara yang juga memiliki nama Kai Renung. Pak Arifin tetua adat Desa menuturkan, tokoh Datu Bendahara ini sekitar tujuh keturunan ke atas. Atau masa hidupnya sekitar awal abad ke-18.

\section{(2). Makam Datu Mandul}

Kira-kira 70 meter dari Makam Datu Bendahara kearah selatan ada sekelompok makam yang juga dikeramatkan. Nisan-nisan makam masih sangat sederhana, makam hanya menggunakan batu monolit sebagai tanda makam. Sebuah makam, ditandai dengan jirat sederhana, dikenal sebagai Datu Mandul. Di samping Makam Datu Mandul, ada bendera kuning yang menandai objek yang dihormati pada makam 
utama. Nama asli tokoh ini tidak diketahui, tetapi masyarakat menyebutnya sebagai Datu Mandul, sekaligus sebagai nama pulau ini.

Secara geografis kedua kompleks makam terletak tidak jauh dari Sungai Mandul, sekitar 20-30 meter. Daerah ini dari segi topografi tidak menguntungkan karena terlalu rendah, sehingga sering banjir dan menurut informasi masyarakat penduduk Pulau Mandul banyak yang mengadu ke luar pulau. Di sekitar sawah-sawah sekitar 500 meter dari komples makam ada toponim kediaman Pangeran Tua. Tokoh ini dianggap sebagai pemilik Tanah Merah, yang penduduknya mayoritas Suku Tidung, komunitas Dayak yang mendominasi wilayah pantai.

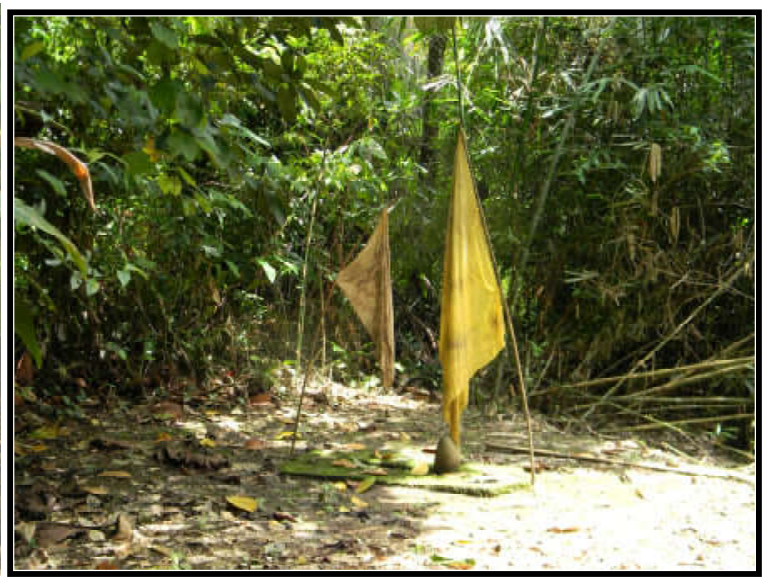

Foto 5. Makam Datu Mandul (dok. Balai Arkeologi Banjarmasin).

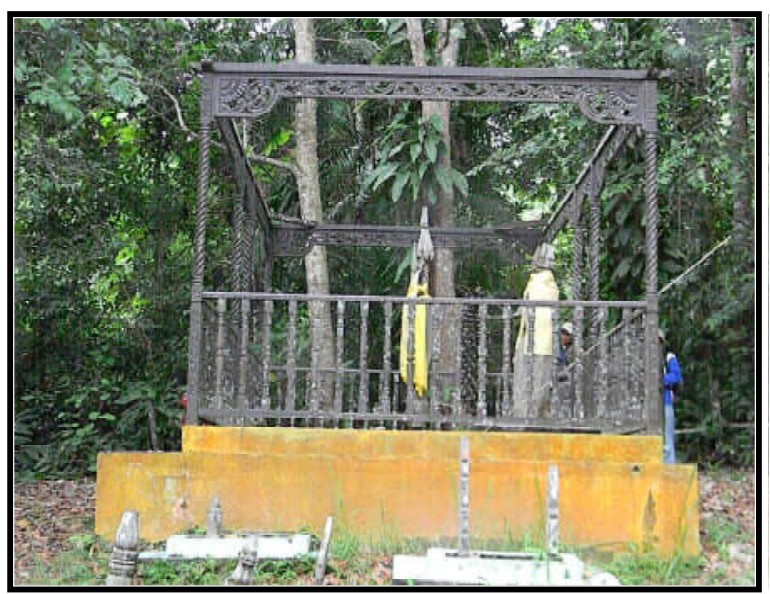

Foto 6. Makam di Tanjung Keramat (dok. Balai Arkeologi Banjarmasin).

(3). Makam Aji Faturrahman di Tanjung Keramat Lokasi makam Tanjung Keramat terletak di Desa Tanjung Keramat, Kecamatan Tanah Lia, Kabupaten Tanah Tidung. Saat ini lokasi kompleks makam berdekatan dengan area persiapan kawasan eksplorasi minyak bumi dan gas milik PT. Medco. Area makam keramat ini di suatu daratan yang menjorok atau tanjung, secara sekilas lokasi ini seperti berada di depan sebuah sungai. Pulau yang ada diseberang adalah Pulau Ligau, wilayah Sembakung, Kabupaten Nunukan.

Lokasi makam utama dibuat pagar keliling yang berbahan dari ulin, tidak ada indikasi tahun pembuatan, tetapi menyiratkan pagar dibuat pada masa kemudian. Komplek makam yang berpagar ini berukuran panjang 6,7 meter, lebar 3,65 meter. Tinggi pagar keliling 2,47 meter. Ada dua makam tokoh utama yang ditandai dengan ukuran nisan yang lebih besar. Adapun makam biasa di dalam pagar ada empat buah.

Makam tokoh utama terbuat dari kayu ulin, dengan bentuk gada. Nisan ini sudah tidak utuh karena sudah rusak dimakan usia. Inskipsi menggunakan dua macam tulisan, huruf Arab Jawi dan huruf kedua ditengarai jenis Lontarak. Tulisan sebagian telah aus, bagian yang terbaca antara lain, menginformasikan nama tokoh, yaitu Aji Faturrahman berangka tahun $1317 \mathrm{H}$, diperkirakan sebagai tahun meninggalnya tokoh tersebut.

\section{Analisis Bukti Arkeologi dan Sejarah a. Hubungan Tidung dengan Dayak}

Tidung dari segi bahasa berarti gunung. Hal ini menyiratkan bahwa pada mulanya Masyarakat Tidung adalah masyarakat yang mendiami wilayah dataran tinggi. Mungkin karena suatu hal, mereka mengadakan migrasi, berpindah melalui Sungai Sesayap atau Sungai Malinau ke daerah hilir mendiami pesisir dan ke pulau-pulau kecil sisi timur Kalimantan lainnya. Dengan melihat bukti sejarah berupa makam - makam di Desa Sesayap, Kecamatan Sesatap Hilir yaitu makam Maharaja Dinda I, dan makam-makam di Pulau Mandul dan di Kecamatan Tanah Lia ditengarai bahwa tempat ini merupakan daerah perpindahan awal mereka berdomisili dan membentuk "suatu institusi" tradisional. Ada kemungkinan mereka terpisahkan dari keluarga suku induknya, yaitu Suku Dayak Murut, sebagaimana digambarkan oleh Tjilik Riwut. Bukti berupa makam, misalnya Datu Bendahara, makam Datu Mandul, makam-makam di Sesayap Hilir menggambarkan bahwa pengaruh Islam telah mengubah tradisi mereka, berbeda dengan saudara-saudara sebelumnya. Pembedaan itu misalnya dengan apa yang dilakukan oleh Dayak Belusu yang mayoritas tidak menganut Islam, dan tradisi masa sebelumnya yang dahulu yaitu tradisi penguburan menggunakan lungun. Contoh ini dapat dilihat pada Lungun llui di Desa Seludau, Sesayap Hilir.

Secara umum ciri kemampuan masyarakat 'Tidung' yang masih mencerminkan spiritual Dayak, yaitu persahabatan dengan alam yang sangat dijaga. 
Situs yang terkait kesatuan manusia dan alam ditengarai adalah Situs Batu Mapan. Bukti ini mengantarkan Suku Tidung merupakan bagian dari komunitas indeginous Kalimantan, yang secara umum disebut Suku Dayak. Seorang yang masih dihormati komunitasnya dan mendiami daerah asal di Malinau adalah tokoh Maharaja Dinda ke-4. la tokoh yang hidup sekitar akhir abad ke-19.

Kedatangan Islam yang secara formal baru terjadi saat pemerintahan Sultan Bulungan dipegang oleh Sultan Muhammad 'Alimuddin. Hal ini ditandai dengan datangnya seorang ulama dari Arab yang singgah dahulu di Demak. Tokoh Islamisasi ini dikenal sebagai Said Abdurrahman Bilfaqih. Pada saat itu, pusat pemerintahan Kesultanan Bulungan di Salim Batu, pindahan dari Baratan yang secara pemerintahan masih tradisional. Di Salim Batu pula bangsawan Bulungan untuk pertama kali bersinggungan dengan Tidung yang memiliki wilayah pantai bagian timur yang hampir bersamaan mengenal Islam untuk pertama kali. Persaingan dan perbedaan latar belakang tak terhindarkan, sekalipun perkawinan politik telah terjadi. Pusat pemerintahan pun kemudian dipindahkan ke Tanjung Palas, yaitu ke bagian lebih hulu. Hal ini konon akibat dari situasi keamanan yang tidak menguntungkan. Penyerangan lanun dari Filipina yang kemungkinan bersekutu dengan bangsawan Tidung penyebabnya. Tidung merasa telah dikuasai oleh Bulungan secara sepihak, disisi lain Tidung tidak simpatik dengan Belanda yang telah mencengkeram Bulungan, mereka pun mulai menjalin hubungan dengan Inggris.

Perlu diketahui bahwa di Salim Batu Islam tumbuh subur dan banyak ulama yang menyiarkan agama, terutama menyebarkan Islam kepada Suku Tidung. Bukti makam ulama penyiar agama Islam banyak ditemukan. Suku Tidung menjadikan Islam sebagai agama masyarakatnya. Bahkan menurut informasi Datu Perdana, di tahun 1948 Suku Tidung dan Sembakung 100 \% beragama Islam (Datu Ferdana, 1948 , 11). Pada saat yang sama diterangkan di saat itu pula, hampir komunitas disekitarnya antara lain Suku Berusu, Tenggalan, Sembuak Abay, suku Putuk, dan Punan belum mengenal agama baru, masih menganut agama lokal $100 \%$.

Islam menjadi identitas Tidung, tetapi di sisi lain komunitas Tidung pun tidak bisa menutup mata bahwa secara genealogis mereka adalah Dayak yaitu ketika keberadaan institusi tradisionalnya bersaing dengan Bulungan. Tidung yang saat itu sebagai penguasa alam yang kaya sumber alam, tetapi tak berdaya menghadapi persaingan dengan Kesultanan Bulungan, apalagi ketika kekuatan imperialis Belanda ikut campur. Secara umum, ciri kemampuan spiritual Dayak adalah persahabatan dan penyatuan dengan alam. Hubungan manusia dan alam sangat dijaga oleh Suku Tidung, misalnya dibuktikan dengan peran Situs Batu Mapan, terletak di Desa Tidung Pala, tidak jauh dari ibu kota kabupaten. Situs ini dipercayai sebagai tempat bersemadi Maharaja Dinda IV.

Sikap penyatuan alam ini, dilandasi oleh penghormatan terhadap peguasa alam yang sangat diyakini akan membuahkan rezeki yang melimpah dan keselamatan. Kesatuan dengan alam yang diaktualisasikan dengan keheningan, menjadikan mereka mampu menyerap getaran alam menjadikan mereka peka dan memiliki kekuatan spiritual lebih.

Pada tradisi Tidung di atas, yang tergambar dari Situs Batu Mapan membuktikan bahwa perilaku budayanya mengatasi ajaran agamanya, yaitu Islam. Lokasi situs ini berada di sekitar air terjul, yang di sebelahnya merupakan bukit. Air terjun ini ada tujuh tingkat, dan pada tingkat paling atas inilah Batu Mapan berada. Arah hadap air terjun beorientasi ke timur laut. Di bawah air terjun tingkat teratas pada kanan kiri air yang menggenang terdapat batu yang dapat digunakan sebagai tempat bersemadi yang secara keseluruhan ruang situs ini. Di batu inilah Maharaja Dinda IV atau Abdul Salam bertapa, seorang keturunan dari Kesultanan Bulungan yang memisahkan diri, sebagai seorang pangeran, merasa prihatin dengan kondisi masyarakat Tidung yang mengalami tekanan di bawah penguasaan wilayah lain (Rakhman, 57tahun). Dari rasa prihatinnya inilah Maharaja Dinda IV ini melakukan bertapa untuk kesempurnaan cita-citanya ini.

Kemungkinan cita-cita yang diinginkan adalah kemandirian wilayah yang memiliki geopolitik yang kuat dan strategis. Batu Mapan merupakan sebuah tempat yang dikeramatkan oleh masyarakat Tideng Pale (Mansyur, 74). Bentuk penghormatan yang lain adalah pemberian sesaji di Batu Mapan bagi orang-orang yang akan memohon kesembuhan kepada Tuhan. Sementara itu pengunjung juga tidak boleh berbicara seenaknya di situs keramat ini. Bagi banyak kalangan di masyarakat berbagai kepercayaan menyebutkan bahwa tidak semua orang dapat masuk ke wilayah ini, bahkan bisa jadi seseorang akan tersesat jika tidak dikehendaki oleh kekuatan gaib jika masuk ke areal situs ini. Sebagai rasa syukur orang yang sudah sampai ke situs ini dengan selamat biasanya dipasanglah kain berwarna yang ditancapkan pada sebatang kayu. Memang bentuk perilaku seperti pemberian sesaji tidak dilakukan oleh beberapa gelintir orang khususnya bagi yang sudah biasa melewati tempat ini. Bagi mereka yang penting tidak usah berbuat macam-macam 
apalagi merusak lingkungan situs ini pasti aman. Bahkan mereka berharap bahwa sebaiknya situs ini tidak terkena dampak pembangunan infrastruktur pusat pemerintahan.

Bentuk-bentuk aktivitas budaya berupa penghormatan terhadap situs ini seolah memberi legitimasi bagi upaya Maharaja Dinda IV yang ingin melepaskan sukunya, Dayak Tidung sebagai suku yang terpinggirkan oleh suasana penjajahan kolonial Belanda yang beralih ke Jepang.

\section{b. Hubungan Islam dengan Tidung}

Bukti arkeologis beberapa makam ulama di sisi timur Kalimantan baik di bagian muara Sungai Kayan (Sungai Bulungan) antara lain: Makam Said Ahmad Maghribi, penyiar agama Islam sekitar abad ke-17 18, makam Habib Al Idrus dan makam Habib Abdullah Bil Faqih yang berdakwah pada masa sesudahnya, semakin mendekatkan Suku Tidung dengan Islam. Apalagi bukti kedekatan lokasi situs yang berdekatan dengan pusat Kerajaan Tidung membuat ikatan dan pengaruh Islam sangat kuat. Kedudukan ulama pun menjadi bagian dari institusi dan pada umumnya berkedudukan sebagai penasehat raja atau orang yang dituakan.

Keberadaan situs Keraton Tidung di Salim Batu yang strategis yang tidak lagi identik dengan gunung sebagaimana Dayak pada umumnya membuat Suku Tidung lebih terbuka baik dalam dunia perdagangan maupun pengaruh sosial budaya. Mobilitas Tidung di pesisir dan pulau-pulau kecil lainnya dibuktikan yaitu dengan peninggalan arkeologi terutama makam, antara lain di tepi Sungai Pemusian di Pulau Tarakan, di Nunukan, dan di Pulau Sebatik.

Kehadiran Habib Alwi bin Al-Kaf di Sesayap, yang merupakan bekas penasehat Kesultanan Bulungan mempengaruhi kehidupan keagamaan sekaligus sikap antiimperialis. Situs makam Habib Alwi al Kaf berdekatan dengan situs makam Maharaja Dinda I menambah pengaruh yang lebih kuat pada ke-Islaman dan sikap anti penjajah Belanda. Di Pulau Mandul, bukti arkeologi berupa makam nenek moyang atau tokoh yang dihormati seperti Datu Bendahara dan Datu Mandul menunjukkan interaksi Suku Tidung dan Islam merata pada daerah pesisir, muara sungai dan pulaupulau kecil. Di sisi lain, ada makam seorang ulama atau seorang bangsawan bernama Aji Faturahman menggambarkan wilayah ini juga berinteraksi dengan masyarakat dari Pulau Sulawesi, yang tampak dari jenis huruf yang dipakai yaitu lontarak.

\section{c. Hubungan Tidung dengan Kesultanan Bulungan}

Pengaruh bangsawan Brunai dan Sulu dapat dianggap sebagai awal dari pengislaman Suku Bulungan dan Suku Tidung. Bangsawan Bulungan secara genealogis mengaitkan diri atau bagian dari Dayak Kayan, sedangkan Tidung di sisi lain merupakan keturunan Dayak Murut. Antara keduanya tampaknya ada persaingan dari segi geopolitis maupun ekonomis. Kesatuan sinergi antara Berau dan Kayan memunculkan Bulungan. Di sisi lain, hegemoni yang dibangun oleh Tidung tampaknya kalah dalam bersaing.

Perkawinan politis Sultan Bulungan Alimuddin dengan 2 istri, yaitu dari Berau dan perkawinan dengan anak seorang 'penguasa Tidung' menyebabkan semakin menunjukkan adanya perebutan dan persaingan. Ada hubungan yang semakin rumit antara Tidung, Berau Bulungan. Saat Sultan Alimuddin memerintah agama Islam dianggap berpengaruh di lingkungan birokrasi. Masalah baru muncul, ketika suksesi pengganti Sultan Alimuddin di kemudian hari. Hal ini menimbulkan friksi dan konflik intern di keluarga kesultanan. Situasi dan kondisi ini diperkeruh dengan kedatangan Belanda. Sebagai negara imperialis mereka berusaha memecah belah keluarga kesultanan dan memihak dengan golongan yang paling menguntungkan dari segi politis maupun ekonomi. Kedudukan Kesultanan Bulungan dan pemisahan diri Tidung sangat menguntungkan Belanda. Pada saat itu eksploitasi minyak bumi ditemukan di Tarakan. Dari segi wilayah Suku Tidung banyak mendiami daerah pesisir dan pulau-pulau kecil, tetapi karena Kesultanan Bulungan relatif dapat dikuasai dan dapat dikendalikan oleh Belanda, maka keberadaan Tidung sebagai kekuatan institusi kekuasaan justru dikaburkan dan dihilangkan dari segi goepolitik.

\section{Kesimpulan}

Melalui analisis bukti arkeologis berupa makam - makam, tradisi dan Situs Batu Mapan, memberi gambaran bahwa Tidung adalah penduduk indigenous, atau bagian dari Bangsa Dayak. Oleh karena pada umumnya Suku Tidung bermukim di pesisir, bagian hilir sungai dan pantai, yang secara lokasional lebih strategis, sehingga mendapat pengaruh dari budaya luar lebih intensif, baik melalui saluran interaksi perdagangan, sosial budaya mempengaruhi agama. Oleh karena persaingan politis 
dan hegemoni menyebabkan identitas mereka berbeda dengan saudara-saudara Dayak lainnya. Hubungan Islam, dengan Tidung memperkaya identitas mereka.

Persaingan hegemoni politis dengan Kesultanan Bulungan menyebabkan Tidung terabaikan, hal ini diperparah oleh kehadiran imperialis Belanda. Politik adu domba dan kepentingan politis imperialis yang berkepentingan atas eksplorasi kekayaan alam minyak bumi, dan perkebunan karet membuat semakin terpuruknya Tidung. Apalagi saat Sultan Bulungan, Sultan Datu Alam Muhammad Adil (1873-1876) yang keturunan Tidung meninggal secara tak wajar. Hegemoni politis kerajaan Tidung sangat lemah dilihat dari sisi bukti arkeologi. Meskipun demikian, keberadaannya perlu diakui.

Hal yang lebih penting dan perlu dipahami adalah bahwa pembentukan daerah-daerah otonom tingkat II, dimaksudkan untuk pemerataan pembangunan lewat desentralisasi kekuasaan. Kita menyadari bahwa pemekaran daerah, bukan berarti menghidupkan lagi primordial-primordial sempit yang mudah dipecah belah dan diadu domba, tetapi bersifat memperdayakan. Semoga Kabupaten Tanah Tidung dapat segera mengejar ketertinggalan dari daerah lain, yaitu dengan membangun dan mewujudkan daerah yang semakin maju dan sejahtera.

\section{Referensi}

Anonim, 2007. http://thetidung.blogspot.com/2007/08/ daftar-nama-raja-raja-yang-memerintah.html

Anonim. 2010. Kabupaten Tidung dalam angka. BPS: Tidung Pala.

Atmojo, Bambang Sakti Wiku. 2002. Penelitian arsitektur makam raja-raja di Kalimantan Timur, Laporan Penelitian Arkeologi Balai Arkeologi Banjarmasin. Belum terbit. 2003. Arsitektur makam raja-raja di kawasan timur Kalimantan. Berita Penelitian Arkeologi 11. Hal. 11-18.

Coomans, Mikhail. 1987. Manusia Daya dahulu, sekarang, masa depan. Jakarta: Gramedia.

Ferdana, Datu (Datu Mohammad Saleh).1948. Risalah riwayat Kesultanan Bulungan tahun 1503 (919 H) hingga 1949. Tidak terbit.

Maunati, Yekti. 2004. Identitas Dayak komodikasi dan politik kebudayaan. Yogyakarta: LKis.
Okushima, Mika. 2004. Ethnic Background of the Tidung: Investigation of the Extinct Rulers of Coastal Northeast Borneo. Pdf.

Riwut, Tjilik. 2003. Maneser panatau tatu Hiang: menyelami kekayaan leluhur. Nila Riwut (penyunting). Palangkaraya: Pusaka Lima.

Susanto, Nugroho Nur. 2010. Makam dan invasi militer di Tarakan. Naditira Widya 3(1): 40-51. 2012. Penelitian eksplorasi peninggalan arkeologi di Kabupaten Bulungan, Kalimantan Timur, Laporan Penelitian Arkeologi, Balai Arkeologi Banjarmasin. Belum terbit. 2013. Penelitian eksplorasi peninggalan arkeologi di Kabupaten Tanah Tidung, Kalimantan Utara, Laporan Penelitian Arkeologi, Balai Arkeologi Banjarmasin. Belum terbit.

Zarkasi. 2010. Zarkasi van bulungan Blocspot.com. 2010.09. Sultan-datu -Alam-Muhammad adll (1873-1876). 


\section{Lampiran}

Masa pra-Kesultanan Bulungan yang dipimpin Oleh Seorang Kesatria/Wira, terdiri atas:

1. Datuk Mencang (Seorang bangsawan dari Brunei), beristrikan Asung Luwan(15551594);

2. Singa Laut, Menantu dari Datuk Mencang (1594-1618);

3. Wira Kelana, Putera Singa Laut (16181640);

4. Wira Keranda, Putera Wira Kelana (16401695);

5. Wira Digendung, putra Wira Keranda (16951731);

6. Wira Amir, Putera Wira Digendung Gelar Sultan Amiril Mukminin (1731-1777).

Urutan penguasa/pimpinan Bulungan era Kesultanan Bulungan

1. Aji Muhammad/Sultan Alimuddin bin Muhammad Zainul Abidin/Sultan Amiril Mukminin/Wira Amir (1877-1817);

2. Muhammad Alimuddin Amirul Muminin Kahharuddin I bin Sultan Alimuddin (jabatan ke-1) (1817-1861);
3. Muhammad Jalaluddin bin Muhammad Alimuddin (1861-1866);

4. Muhammad Alimuddin Amirul Muminin Kahharuddin I bin Sultan Alimuddin (jabatan ke-2) (1866-1873);;

5. Muhammad Khalifatul Adil bin Maoelanna (1873-1875);

6. Muhammad ;Kahharuddin II bin Maharaja Lela (1875-1889);

7. Sultan Azimuddin bin Sultan Amiril Kaharuddin (1889-1899);

8. Pengian Kesuma (1899-1901). la adalah istri Sultan Azimuddin;

9. Sultan Kasimuddin;

10. Datu Mansyur (1925-1930), Pemangku jabatan sultan;

11. Maulana Ahmad Sulaimanuddin (19301931);

12. Maulana Muhammad Jalaluddin (19311958). 